\author{
Research article \\ urn:Isid:zoobank.org:pub:3645CA2E-F2CE-41FB-91EA-48999065936B
}

\title{
Contributions to the knowledge of the mite genus Stigmaeus Koch, 1836 (Acari: Stigmaeidae) of Turkey
}

\author{
Meryem BİNGÜL ${ }^{1}$, Salih DOĞAN ${ }^{2, *} \&$ Sibel DİLKARAOĞLU ${ }^{3}$ \\ 1,2,3 Biology Department, Arts \& Sciences Faculty, Erzincan University, Erzincan, Turkey. \\ *Corresponding author: salihdogan@erzincan.edu.tr \\ ${ }^{1}$ Email: mbingul@erzincan.edu.tr \\ ${ }^{3}$ Email: sdilkara@erzincan.edu.tr \\ ${ }^{1}$ urn:Isid:zoobank.org:author:304DEF15-095F-41FE-9C2F-7B8E1B70B413 \\ ${ }^{2}$ urn:1sid:zoobank.org:author:2444C602-B47B-4D8F-B446-DCBC2AD354FB \\ ${ }^{3}$ urn:1sid:zoobank.org:author:9D99E481-4E14-4B08-9EC8-F1F2807C54EF
}

\begin{abstract}
Based on the mite specimens collected within the scope of a study on Erzincan (Turkey) mite biodiversity, two species of the genus Stigmaeus are described and illustrated here: S. bifurcus sp. nov. as new to science and S. miandoabiensis Bagheri \& Zarei, 2012 as a new record for Turkey. Some morphological abnormalities in the new species are noted. The deutonymph of $S$. miandoabiensis is described for the first time in this study. Discovery of this stage from soil and litter under Pinus sylvestris in Turkey adds more data to our knowledge of the species.
\end{abstract}

Keywords. Mite, taxonomy, Stigmaeus, new species, new record, description, Turkey.

Bingül M., Doğan S. \& Doğan S. 2017. Contributions to the knowledge of the mite genus Stigmaeus Koch, 1836 (Acari: Stigmaeidae) of Turkey. European Journal of Taxonomy 307: 1-16. https://doi.org/10.5852/ejt.2017.307

\section{Introduction}

Stigmaeus Koch, 1836 is the most diverse genus in the family Stigmaeidae with 133 valid species (Fan \& Zhang 2005; Doğan et al. 2015a, 2016; Dilkaraoğlu et al. 2016a, 2016b, Fan et al. 2016). To date, 36 species of the genus have been recorded from Turkey (Özkan et al. 1988, 1994; Erman et al. 2007; Doğan 2007; Doğan et al. 2015a, 2016; Dilkaraoğlu et al. 2016a, 2016b).

The descriptions of Stigmaeus bifurcus sp. nov. and S. miandoabiensis Bagheri \& Zarei, 2012 — originally found in Iran, newly recorded for the Turkish fauna-are given in this survey. The deutonymph of S. miandoabiensis is described for the first time. 


\section{Material and methods}

The specimens were collected from Erzincan in 2014 and 2015. Methods used for specimen collection, extraction, material preservation and preparation were as discussed by Doğan (2006). The specimens were illustrated using a Leica DM $4000 \mathrm{~B}$ phase-contrast microscope. The nomenclature of the idiosomal shields follows that of Summers (1962). Dorsal setal and leg setal designations follow Kethley (1990) and Grandjean (1944), respectively. Setal counts of leg segments are given with solenidia in parentheses. All measurements are given in micrometers $(\mu \mathrm{m})$ and refer to the length of the structure unless otherwise stated. For the new species, measurements of the holotype are given first followed in parentheses by those of paratypes as a range. In newly recorded species, mean values are given first and the range is given parenthetically. Body length measurements represent the distance between the base of the gnathosoma and the posterior part of the idiosoma; width was measured at the broadest point of the idiosoma. Setae were measured from the setal base to the tip of the seta; distances between setae were measured between the setal bases. Leg length was measured from the tip of the claws to the trochanter base. Palp length was measured from the tarsal tip to the trochanter base. Specimens examined were deposited in the collection of the Acarology Laboratory of Erzincan University, Turkey.

\section{Abbreviations}

\section{Gnathosoma}

$\omega=$ solenidion on palptarsus

elcp $=$ supracoxal setae of palp

$m=$ anterior or innermost pair of subcapitular setae

$n=$ posterior pair of subcapitular setae

or $1=1^{\text {st }}$ pair of adoral setae

$o r_{2}=2^{\text {nd }}$ pair of rostral setae

\section{Idiosoma}

$1 a=1^{\text {st }}$ pair of intercoxal setae

$3 a=2^{\text {nd }}$ pair of intercoxal setae

$4 a=3^{\text {rd }}$ pair of intercoxal setae

$a g_{1}=1^{\text {st }}$ pair of aggenital setae

$a g_{2}=2^{\text {nd }}$ pair of aggenital setae

$a g_{3}=3^{\text {rd }}$ pair of aggenital setae

$a g_{4}=4^{\text {th }}$ pair of aggenital setae

$c_{1}=$ internal pair of humeral setae

$c_{2}=$ external pair of humeral setae

$d_{1}=$ internal pair of dorsal setae

$d_{2}=$ external pair of dorsal setae

$e_{1}=$ internal pair of lumbral setae

$e_{2}=$ external pair of lumbral setae

$f_{1}=$ internal pair of sacral setae

$g_{1}=1^{\text {st }}$ pair of genital setae

$g_{2}=2^{\text {nd }}$ pair of genital setae

$h_{1}=1^{\text {st }}$ pair of clunal setae

$h_{2}=2^{\text {nd }}$ pair of clunal setae

$h_{3}=3^{\text {rd }}$ pair of clunal setae

pob $=$ post-ocular bodies 


$$
\begin{aligned}
p s_{1} & =1^{\text {st }} \text { pair of pseudanal setae } \\
p s_{2} & =2^{\text {nd }} \text { pair of pseudanal setae } \\
p s_{3} & =3^{\text {rd }} \text { pair of pseudanal setae } \\
s c e & =\text { external pair of scapular setae } \\
s c i & =\text { internal pair of scapular setae } \\
v i & =\text { internal pair of vertical setae } \\
v e & =\text { external pair of vertical setae } \\
\text { Legs } & \\
\omega & =\text { solenidion on tarsi } \\
\varphi & =\text { solenidion on tibia I } \\
\varphi \rho & =\text { proximal solenidion on tibiae } \\
\kappa & =\text { solenidion on genu I } \\
e l c p & =\text { supracoxal setae of leg I }
\end{aligned}
$$

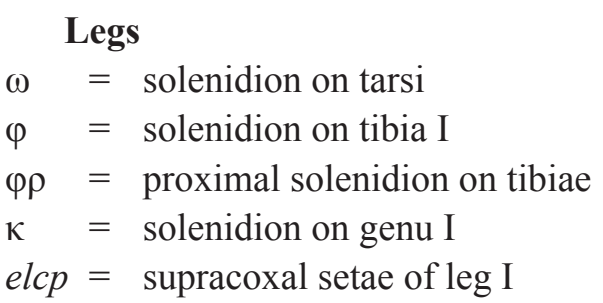

\title{
Institutional abbreviation
}

ALEU = Acarology Laboratory of Erzincan University, Turkey

\section{Results}

\author{
Subclass Acari Leach, 1817 \\ Superorder Acariformes Zakhvatkin, 1952 \\ Order Trombidiformes Reuter, 1909 \\ Suborder Prostigmata Kramer, 1877 \\ Superfamily Raphignathoidea Kramer, 1877 \\ Family Stigmaeidae Oudemans, 1931 \\ Genus Stigmaeus Koch, 1836
}

\section{Type species}

Stigmaeus cruentus Koch, 1836, by original designation.

\section{Description}

The genus Stigmaeus Koch, 1836 (Acari: Stigmaeidae) can be defined by the following characters: idiosoma oval; chelicerae separate; palptibial claw subequal to or slightly shorter than palptarsus; accessory claw seta-like or spine-like, terminal eupathidion on palptarsus basally fused and split into two or three long prongs; counts of setae and solenidia from palptrochanter to palptarsus: $0,3,1-2,2+1$ claw +1 accessory claw, $4+1 \omega+1$ subterminal spine-like eupathidion +2 or 3 eupathidia (basally fused); subcapitulum with two pairs of subcapitular setae; prodorsum typically with a large shield, bearing three pairs of setae and a pair of platelets bearing setae sce; eyes present or absent, postocular bodies (pob) present or absent; dorsal hysterosomal area typically with one or two shields surrounded by three to five pairs of platelets, setae $d_{1}$ and $d_{2}$ never on same shield; humeral shields dorso- or ventrolateral, with setae $c_{2}$; intercalary shields entire or divided, with a pair of setae $\left(f_{1}\right)$; suranal shield entire or divided, with two or three pairs of setae; coxisternal shields present, divided along midline; ventral opisthosoma with three to five pairs of aggenital setae; genital and anal valves fused or contiguous, with one to three pairs of genital setae and three pairs of pseudanal setae (Fan \& Zhang 2005; Dönel \& Doğan 2011; Doğan et al. 2015a, 2016). 
Stigmaeus bifurcus sp. nov.

urn:1sid:zoobank.org:act:2EB6B605-F3AA-4142-8692-BD150A8A85D0

Figs 1-2; Table 1

\section{Etymology}

The name of this new species, bifurcus, refers to the shape of the eupathidion on the palptarsus.

\section{Type material}

\section{Holotype}

TURKEY: , from soil under Ulmus sp., Erzincan, alt. 1275 m, 39³9'39.8" N, 39²9'28.5" E, 25 Oct. 2015.

\section{Paratypes}

TURKEY: 8 q+ , same data as holotype; 1 , from soil under Rosa canina, same locality as holotype, 15 Mar. 2015.

\section{Description}

\section{Female}

IDIOSOMA. Elongated. Length of body (including gnathosoma): 396 (350-384). Width of body: 163 (129-157).

Gnathosoma (Fig. 2B). Gnathosoma punctate and 68 (65-70) long, chelicerae separate and punctate, 78 (74-81) long. Palp punctate and 91 (74-89) long. Counts of setae and solenidia from palptrochanter to palptarsus: $0,3,1,2+1$ claw +1 seta-like accessory claw, $4+1$ solenidion +1 subterminal seta-like eupathidion +1 bifurcate eupathidion. Palptibial claw slightly longer than palptarsus. Palp supracoxal setae (elcp) pudgy. Subcapitulum with two pairs of adoral setae $\left(\right.$ or $\left._{1,2}\right)$ and two pairs of subcapitular setae $(m, n)$. Dimensions and distance between subcapitular setae, $m 14$ (12-14), $n 26$ (22-25), $m-m 21$ (19-22), $n-n 24$ (23-26), $m-n 12$ (10-12).

Dorsum (Figs 1A, C-D, 2A). Integument striate except punctate peritremal region, propodosomal shield with reticulations, its posterior margin concave and with tubercles. Propodosomal shield bearing three pairs of setae ( $v i, v e, s c i$ ) and apodemal marking, eyes and post-ocular bodies absent. Setae sce on minute platelets. Central shield vaguely reticulate but other shields not ornamented. Central shield bearing two pairs setae $\left(c_{1}, d_{1}\right)$. In one paratype specimen left member of setae $c_{l}$ about twice as long as right member (Fig. 1C). Setae $d_{2}$ located on marginal shield. Setae $e_{1}$ on divided median zonal shields. Setae $e_{2}$ located on minute platelets. Setae $f_{l}$ on divided intercalary shield. One pair of extra, minute and non-setose shields lateral to intercalary shields. Suranal shield divided and with three pairs of setae $\left(h_{l-3}\right)$ but right member of setae $h_{3}$ absent in one paratype (Fig. 1D). Setae $v i, s c i, d_{1}$ and all suranal setae slightly serrated but others smooth (Fig. 2A). Lengths and distances of dorsal idiosomal setae as follows: vi 16 (14-17), ve 42 (38-47), sci 20 (17-20), sce 41 (40-44), c 16 (15-17), c 46 (45-49), d 16 (16-18), $d_{2} 34$ (29-35), e 8 (17-20), $e_{2} 18$ (17-19), f 31 (34-38), $h_{1} 21$ (21-26), $h_{2} 24$ (21-26), $h_{3} 13$ (13-15), vi-vi 23 (24-29), ve-ve 33 (31-35), vi-ve 20 (19-22), sci-sci 46 (43-48), ve-sci 36 (33-35), sce-sce 99 (86-104), sci-sce 27 (23-29), $c_{1}-c_{1} 31$ (26-31), $c_{2}-c_{2} 145$ (124-145), $c_{1}-c_{2} 63$ (46-66), $d_{2}-d_{2} 100$ (89-102), $c_{1}-d_{1} 43$ (40-46), $c_{1}-d_{2} 41$ (35-41), $d_{1}-d_{1} 28$ (27-31), $d_{2}-d_{1} 43$ (39-43), $e_{2}-e_{2} 96$ (83-97), $d_{2}-e_{2} 62$ (51-61), $d_{1}-e_{1} 47$ (40-49), $d_{1}-e_{2} 51$ (44-49), $e_{1}-e_{1} 32$ (29-37), $e_{2}-e_{1} 34$ (27-37), $f_{1}-f_{1} 46$ (43-51), $e_{1}-f_{1} 26(24-26), e_{2}-f_{1} 42$ (36-43), $f_{1}-h_{1} 40$ (35-46), $f_{1}-h_{2} 40$ (30-43), $f_{1}-h_{3} 41$ (27-36), $h_{1}-h_{1} 23$ (22-26), $h_{2}-h_{2} 52$ (48-54), $h_{3}-h_{3}$ 70 (57-66), $h_{1}-h_{2} 16(12-14), h_{2}-h_{3} 9(6-9)$. 


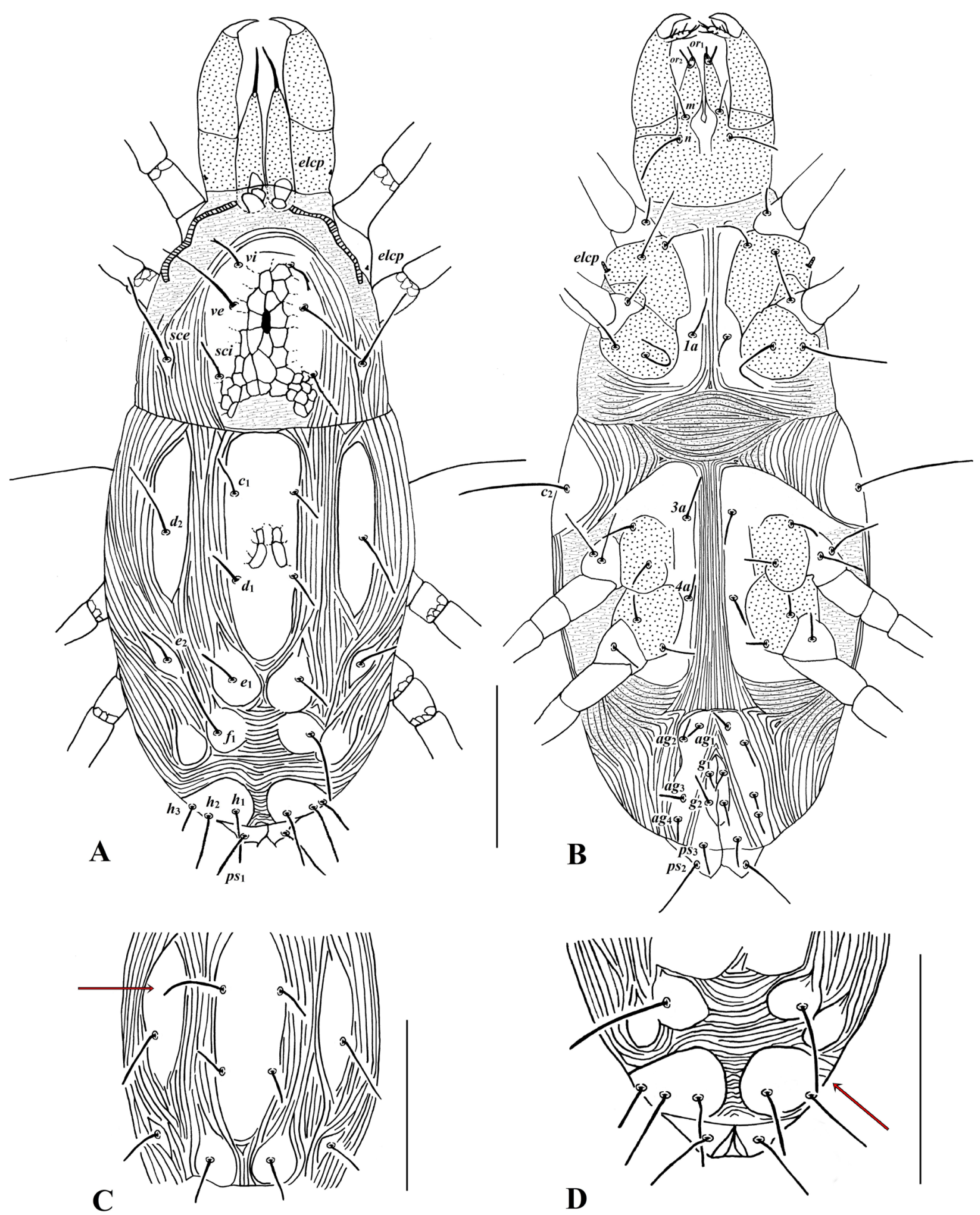

Fig. 1. Stigmaeus bifurcus sp. nov. A-B. Holotype ( + ). A. Dorsum of body. B. Venter of body. C-D. Paratype (q). C. Abnormality: left seta $c_{1}$ about 2 times as long as the right. D. Abnormality: seta $h_{3}$ absent on right suranal shield in one paratype. Scale bars $=100 \mu \mathrm{m}$. 

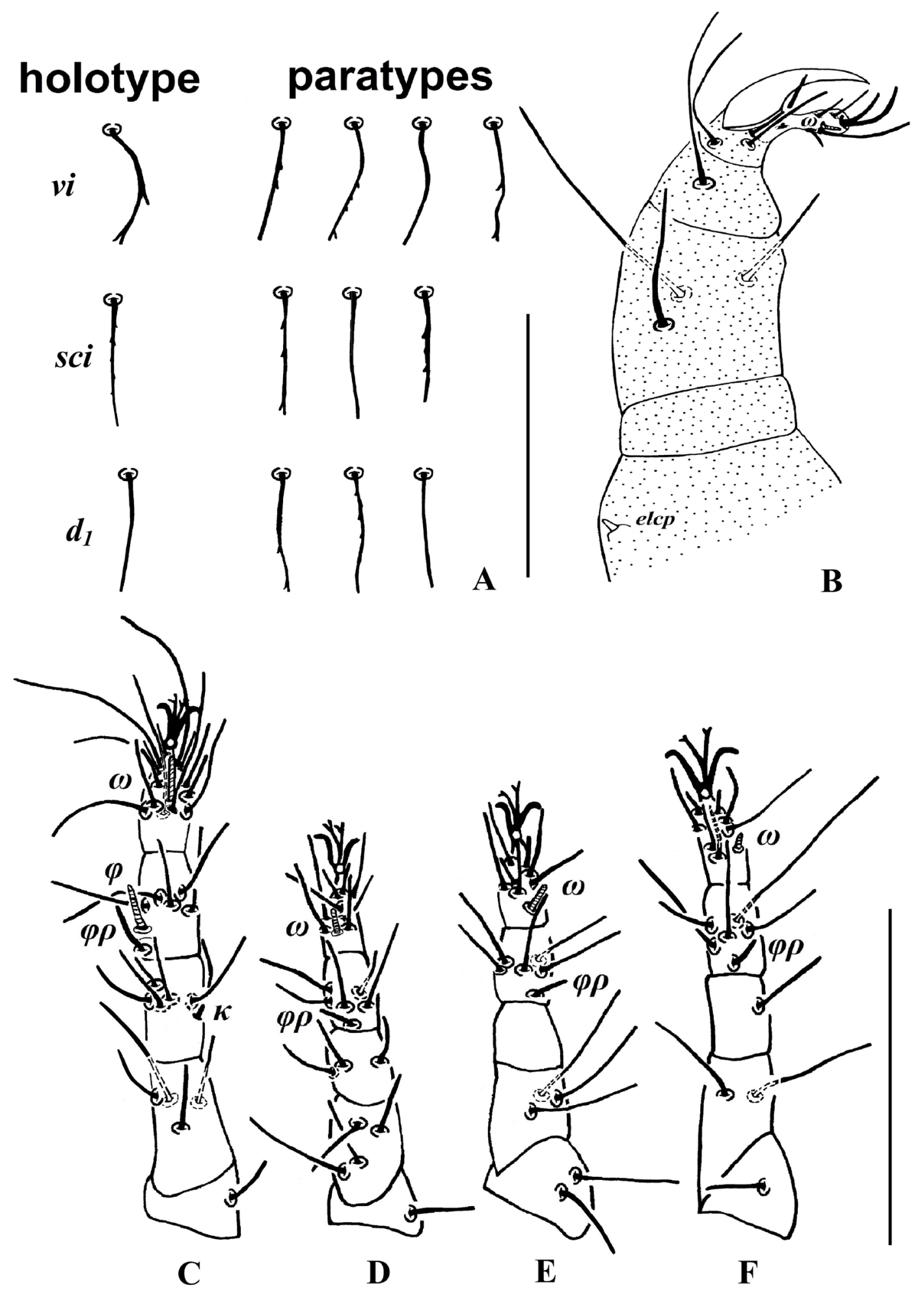

Fig. 2. Stigmaeus bifurcus sp. nov., holotype, +. A. Some dorsal body setae. B. Palp. C. Leg I. D. Leg II. E. Leg III. F. Leg IV. Scale bars: A-B $=40 \mu \mathrm{m} ; \mathrm{C}-\mathrm{F}=100 \mu \mathrm{m}$. 


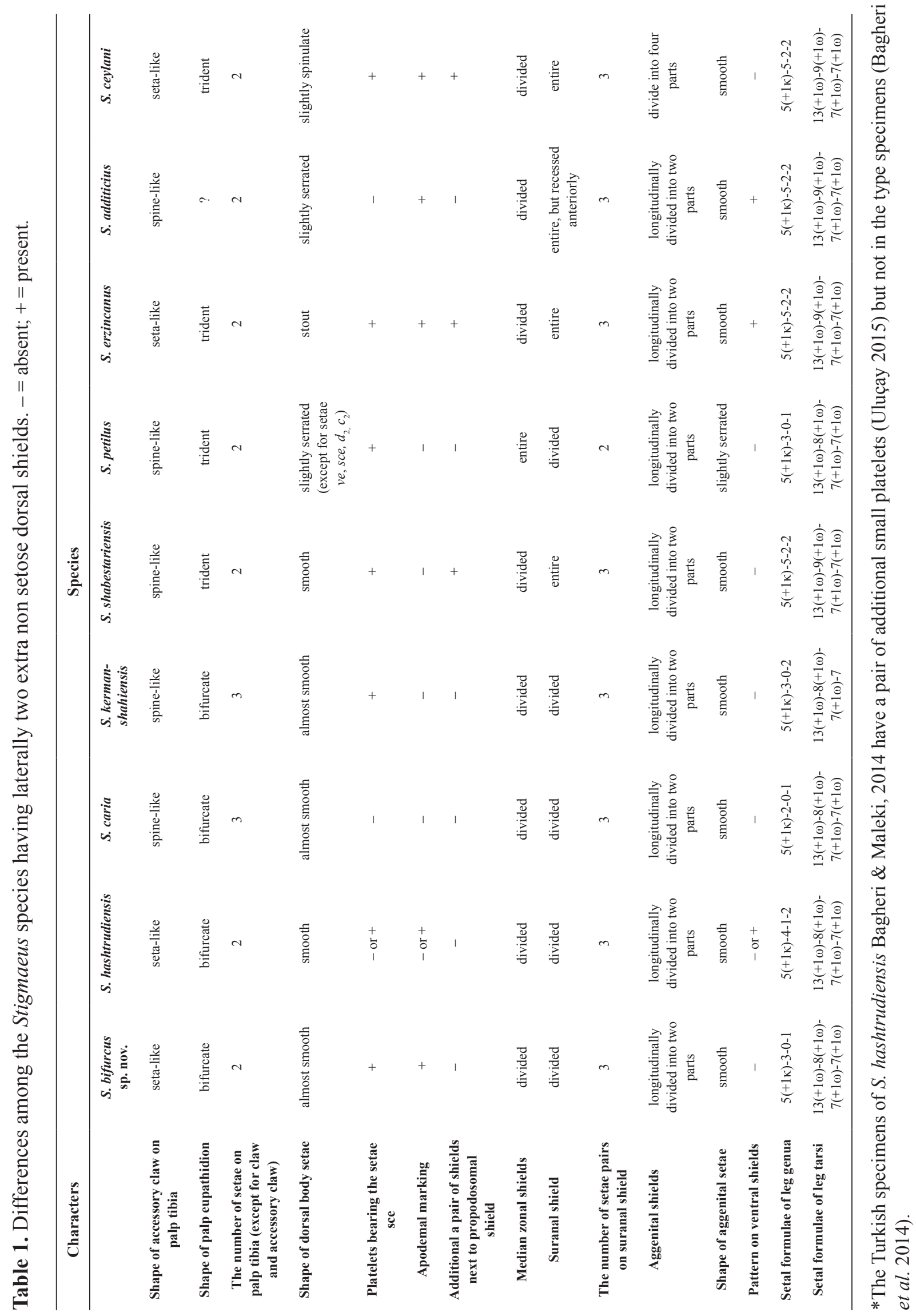


Venter (Fig. 1B). Almost striate. Back of coxae I-II and III-IV striate with tubercles. Humeral shields without reticulations and bearing setae $c_{2}$. Coxisternal shields divided, smooth and bearing three pairs of setae (1a, 3a, 4a). Lengths and distances of these setae: 1a 14 (12-13), 3a 14 (12-14), 4a 14 (11-14), $1 a-1 a 17$ (17-21), 3a-3a 23 (20-29), 4a-4a 23 (16-26). Genital and anal shields contiguous, two pairs of smooth genital $\left(g_{1,2}\right)$ and three pairs of slightly serrate pseudanal setae $\left(p s_{1-3}\right) \cdot p s_{3}$ shorter than other pseudanal setae. Four pairs of aggenital setae $\left(a g_{I-4}\right)$ on long and divided aggenital shields. Lengths of these setae as follows: $a g_{1} 10$ (8-10), $a g_{2} 10$ (8-10), $a g_{3} 10$ (8-10), $a g_{4} 11$ (9-11), $g_{1} 7$ (6-9), $g_{2} 12$ (10-13), $p s_{1} 27$ (23-27), $p s_{2} 25$ (22-25), ps 13 (12-14).

Legs (Figs 2C-F). Coxae I-IV with punctation. Length: leg I 138 (136-140), leg II 106 (100-107), leg III 114 (108-115), leg IV 128 (121-129). Counts of setae and solenidia on legs I-IV: coxae 2-2-

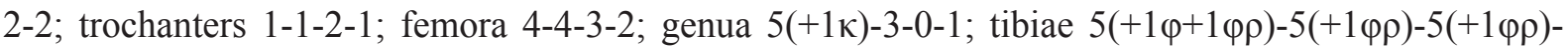
$5(+1 \varphi \rho)$; tarsi $13(+1 \omega)-8(+1 \omega)-7(+1 \omega)-7(+1 \omega)$. All tarsi with solenidia. Lengths of solenidia: I $\omega 11$ (8-12), II 18 (7-9), III 6 (3-5), IV 6 6 (3-5).

\section{Male and immature stages \\ Unknown.}

\section{Remarks}

This new species resembles Stigmaeus kermanshahiensis Khanjani et al., 2012 and S. caria Khanjani et al., 2012 in that the eyes and post-ocular bodies are absent, suranal shield divided, one pair of extra, minute and non-setose shields lateral to the intercalary shields, and the palp tarsus bears a bifurcate eupathidium. However, it can be separated from S. kermanshahiensis by the following characters: one seta on genu IV (vs two setae in S. kermanshahiensis), palptibia with two setae (vs three setae in S. kermanshahiensis), and apodemal marking present (absent in S. kermanshahiensis). Stigmaeus bifurcus sp. nov. can also be distinguished from $S$. caria by the following characters: three setae on genu II (vs two setae in S. caria), palptibia with two setae (vs three setae in $S$. caria), sce on minute platelets (on striate integument in $S$. caria), and apodemal marking present (absent in $S$. caria). The new species is also similar to $S$. hashtrudiensis Bagheri \& Maleki, 2014; however, it differs from the latter

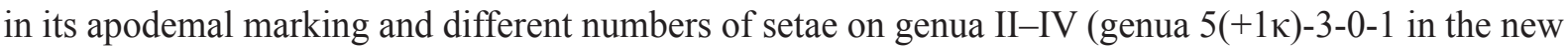

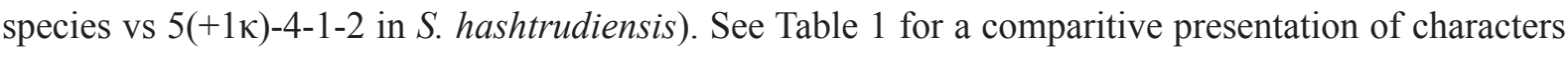
among different Stigmaeus species.

Stigmaeus miandoabiensis Bagheri \& Zarei, 2012

Figs 3-5

\section{Material examined}

TURKEY: 2 우, 1 DN from soil and litter under Pinus sylvestris, Erzincan, alt. $1210 \mathrm{~m}, 39^{\circ} 45^{\prime} 00.8^{\prime \prime} \mathrm{N}$, $39^{\circ} 29^{\prime} 17.8^{\prime \prime}$ E, 23 Oct. 2014; 1 from soil under Rosa canina, Erzincan, 1275 m, 39³9'39.8" N, 39²9'28.5" E, 15 Mar. 2015.

\section{Description}

Female (Figs 3, 5) $(\mathrm{n}=3)$

IDIOSOMA. Oval. Length of body (including gnathosoma): 350 (335-371). Width of body: 120 (114-128).

Gnathosoma (Fig. 5B). Gnathosoma punctate and 68 (67-71) long, chelicerae separate and punctate, 79 (74-82) long. Palp punctate and 73 (69-79) long. Counts of setae and solenidia from palptrochanter to palptarsus: $0,3,1,2+1$ claw +1 seta like accessory claw, $4+1$ solenidion +1 subterminal seta-like eupathidion +1 bifurcate eupathidion. Palptibial claw about subequally as long as palptarsus. Palpal 


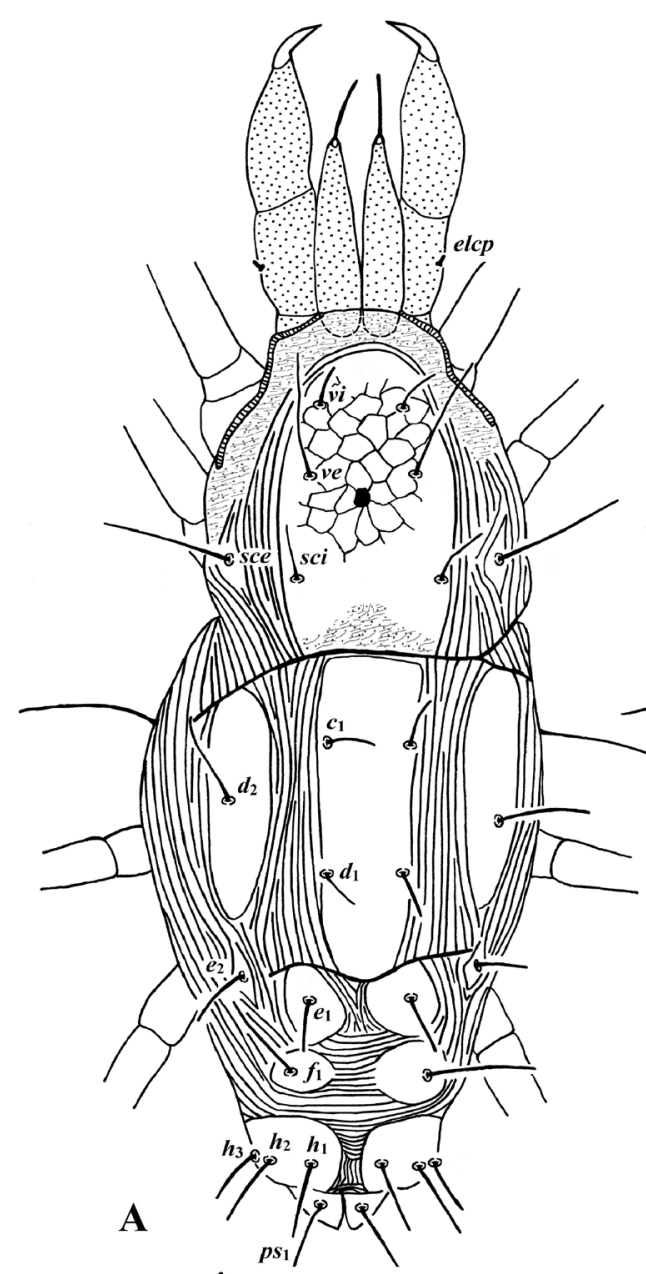

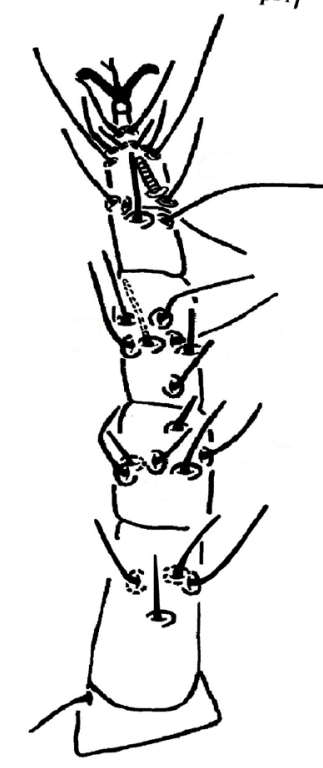

C

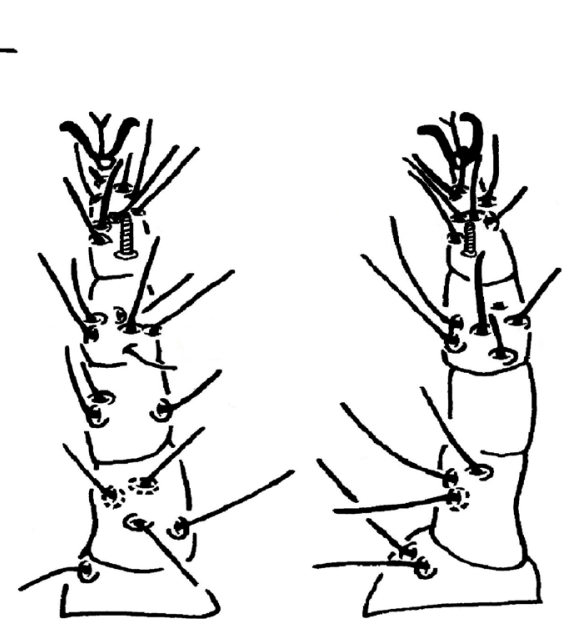

D

$\mathbf{E}$

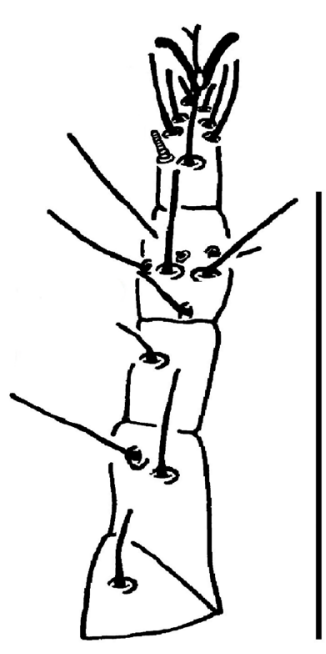

$\mathbf{F}$

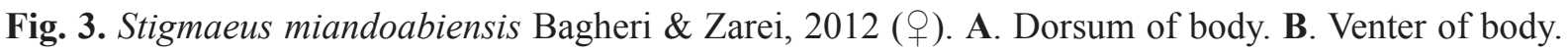
C. Leg I. D. Leg II. E. Leg III. F. Leg IV. Scale bars $=100 \mu \mathrm{m}$. 

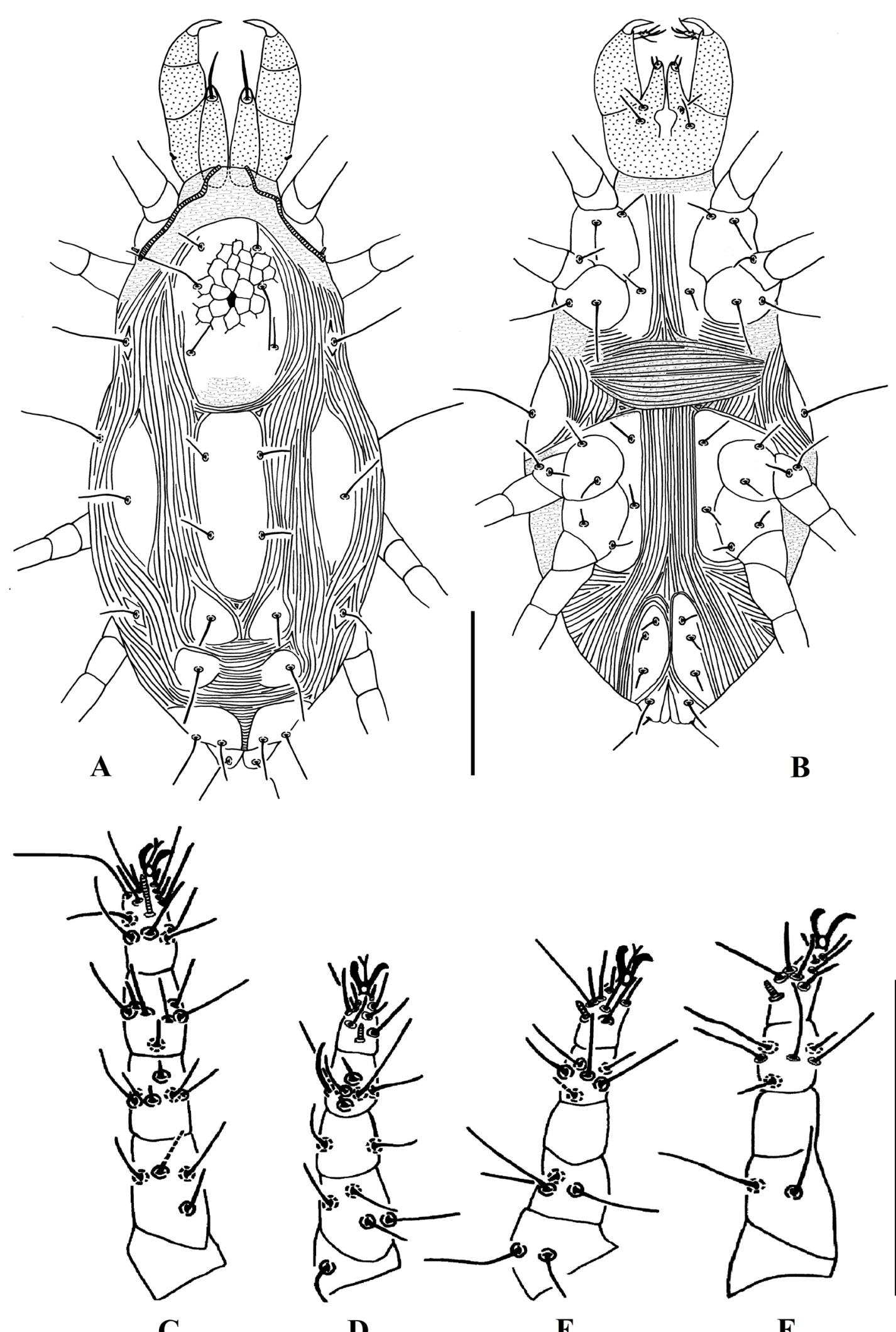

C

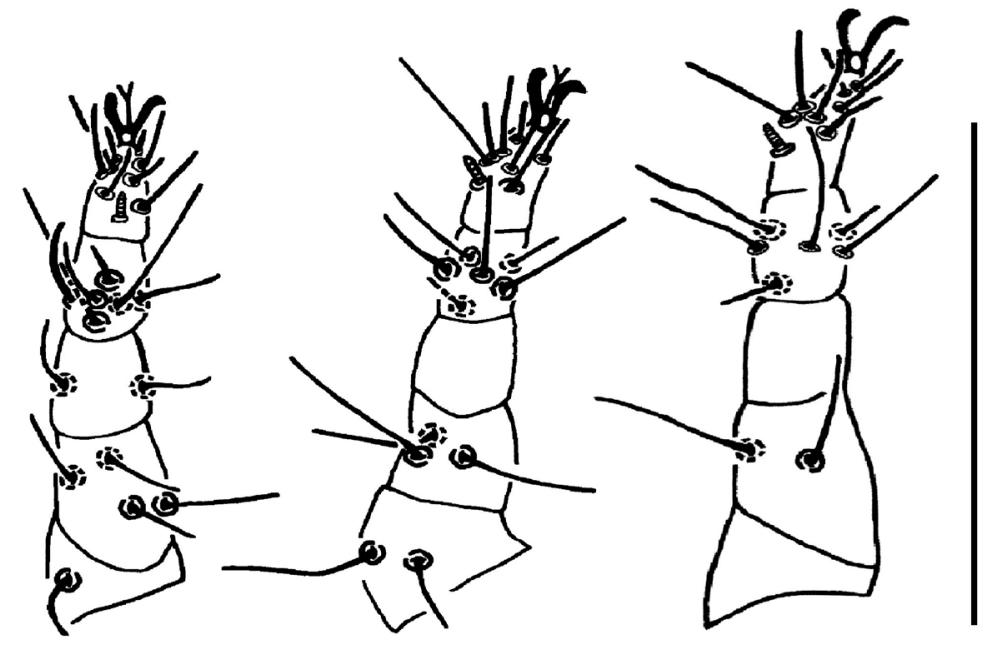

D

$\mathbf{E}$

F

Fig. 4. Stigmaeus miandoabiensis Bagheri \& Zarei, 2012 (deutonymph). A. Dorsum of body. B. Venter of body. C. Leg I. D. Leg II. E. Leg III. F. Leg IV. Scale bars $=100 \mu \mathrm{m}$. 
supracoxal setae (elcp) pudgy. Subcapitulum with two pairs of adoral setae $\left(\right.$ or $\left._{1,2}\right)$ and two pairs of subcapitular setae $(m, n)$. Dimensions and distance between subcapitular setae: $m 11$ (11-12), $n 16$ (16-17), $m-m 21$ (18-24), $n-n 23$ (23-24), $m-n 11$ (8-12).

Dorsum (Figs 3A, 5A). Integument striate except punctate peritremal region. Propodosomal shield with reticulations, its anterior and posterior margin with tubercles. Propodosomal shield bearing three pairs of setae ( $v i, v e, s c i$ ) and apodemal marking, eyes and post-ocular bodies absent. Setae sce on minute platelets. Central shield bearing two pairs of setae $\left(c_{1}, d_{1}\right)$. Setae $d_{2}$ located on marginal shield. Setae $e_{1}$ on divided median zonal shields. Setae $e_{2}$ located on minute platelets. Setae $f_{1}$ on divided intercalary shield. Suranal shield divided and with three pairs of setae $\left(h_{1-3}\right)$. Setae $v i, s c i, c_{1,} d_{1}$ and $e_{1}$ slightly serrated but others smooth (Fig. 5A). Lengths and distances of dorsal idiosomal setae as follows: vi 13 (12-16), ve 41 (40-41), sci 18 (17-20), sce 40 (39-40), c 15 (14-18), c 45 (43-46), $d_{1} 15$ (14-16), $d_{2}$ 25 (18-31), e 18 (15-22), e 17 (16-17), f, 31 (28-34), hl 21 (20-22), h, 20 (20-21), h 15 (15-15), vi-vi 25 (24-26), ve-ve 33 (32-35), vi-ve 22 (20-23), sci-sci 45 (44-46), ve-sci 34 (32-35), sce-sce 86 (82-91), sci-sce 23 (20-25), c c - c 28 (27-29), $c_{2}-c_{2} 115$ (107-124), $c_{1}-c_{2} 49$ (48-51), $d_{2}-d_{2} 90$ (82-99), $c_{1}-d_{1} 40$ (39-42), $c_{1}-d_{2} 38$ (34-43), $d_{1}-d_{1} 26$ (24-28), $d_{2}-d_{1} 36$ (32-40), $e_{2}-e_{2} 76$ (70-86), $d_{2}-e_{2} 54$ (52-57), $d_{1}-e_{1} 43$ (40-45), $d_{1}-e_{2} 42$ (40-46), $e_{1}-e_{1} 31$ (29-35), $e_{2}-e_{1} 24$ (22-28), $f_{1}-f_{1} 44$ (41-48), $e_{1}-f_{1}$ 24 (24-25), $e_{2}-f_{l} 37$ (34-41), $f_{1}-h_{1} 32$ (28-36), $f_{l}-h_{2} 28$ (26-30), $f_{l}-h_{3} 27$ (27-27), $h_{l}-h_{1} 21$ (20-23), $h_{2}-h_{2} 46(44-48), h_{3}-h_{3} 55(53-57), h_{1}-h_{2} 14(13-14), h_{2}-h_{3} 7(6-8)$.

\section{Females Deutonymph}

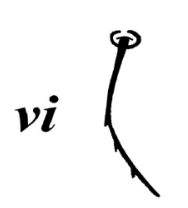

sci

$c_{1} \uparrow$

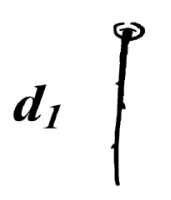

A
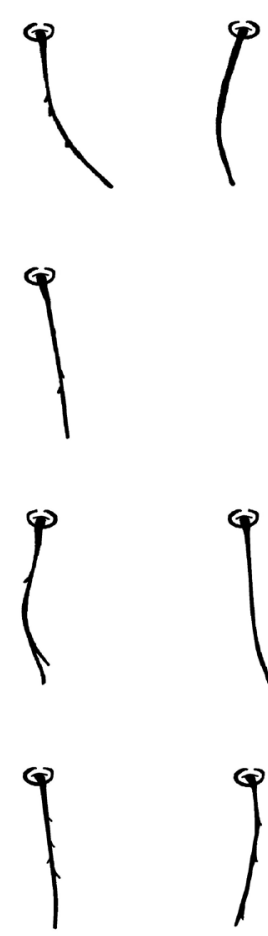
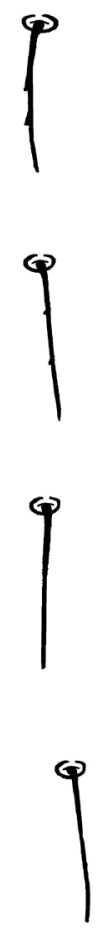

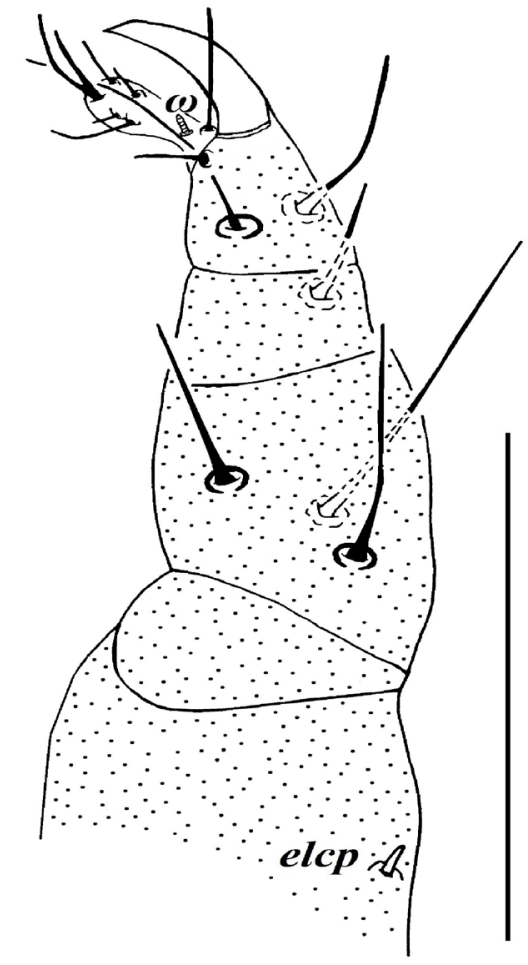

B

Fig. 5. Stigmaeus miandoabiensis Bagheri \& Zarei, 2012. A. Some dorsal body setae. B. Palp (†). Scale bars $=40 \mu \mathrm{m}$. 
Venter (Fig. 3B). Almost striate. Back of coxae II and III-IV striate with tubercles. Humeral shields without ornamentation, bearing setae $c_{2}$. Coxisternal shields divided, without ornamentation, bearing three pairs of setae $(1 a, 3 a, 4 a)$. Lengths and distances of these setae: $1 a$ 12 (11-13), $3 a 12(11-13), 4 a 11$ (10-13), 1a-1a 19 (17-20), 3a-3a 23 (18-26), 4a-4a 21 (18-23). Genital and anal shields contiguous, two pairs of genital $\left(g_{1,2}\right)$ and three pairs of pseudanal setae $\left(p s_{1-3}\right), p s_{3}$ shorter than other pseudanal setae. Four pairs of aggenital setae $\left(a g_{l-4}\right)$ on long and divided aggenital shields. Lengths of these setae as follows: $a g_{1} 9$ (8-9), $a g_{2} 9$ (8-9), $a g_{3} 9$ (8-9), $a g_{4} 10$ (9-10), $g_{1} 8$ (7-9), $g_{2} 9$ (7-10), $p s_{1} 24$ (23-25), $p s_{2} 21(19-23), p s_{3} 11(11-11)$.

LeGs (Figs 3C-F). Lengths: leg I 136 (133-142), leg II 100 (97-105), leg III 103 (102-106), leg IV 125 (118-132). Counts of setae on legs I-IV: coxae 2-2-2-2, trochanters 1-1-2-1, femora 4-4-3-2, genua

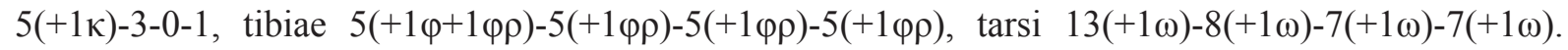
Lengths of solenidia: I $\omega 10$ (10-10), II $\omega 8$ (8-8), III $\omega 4$ (4-5), IV $\omega 5$ (4-6).

Deutonymph (DN) (Figs 4-5) $(\mathrm{n}=1)$

IDIOSOMA. Length of body (including gnathosoma): 334. Width of body: 136 .

Gnathosoma. Lengths: gnathosoma 60, chelicerae 69, palp 68. Number of setae on palp segments as in female. Dimensions and distance between subcapitular setae: $m 12, n 15, m-m 18, n-n 23, m-n 10$.

Dorsum (Fig. 4A). As in female except suranal shields with two pairs of setae. Lengths and distances of dorsal idiosomal setae as follows: vi 13, ve 36, sci 16, sce 33, $c_{1} 13, c_{2} 41, d_{1} 13, d_{2} 21, e_{1} 14, e_{2} 14, f_{1} 26$, $h_{1} 7, h_{2} 20, v i-v i$ 26, ve-ve 29, vi-ve 17, sci-sci 39, ve-sci 31, sce-sce 96, sci-sce 29, $c_{1}-c_{1}$ 27, c-c $c_{2} 130$, $c_{1}-c_{2} 52, d_{2}-d_{2} 99, c_{1}-d_{1} 37, c_{1}-d_{2} 41, d_{1}-d_{1} 23, d_{2}-d_{1} 42, e_{2}-e_{2} 94, d_{2}-e_{2} 55, d_{1}-e_{1} 41, d_{1}-e_{2} 52, e_{1}-e_{1} 30$, $e_{2}-e_{1} 30, f_{1}-f_{1} 40, e_{1}-f_{1} 23, e_{2}-f_{1} 37, f_{1}-h_{1} 34, f_{1}-h_{2} 29, h_{1}-h_{1} 19, h_{2}-h_{2} 41, h_{1}-h_{2} 11$.

Venter (Fig. 4B). Ventral view similar to that of female but genital shield and its setae absent, aggenital shields bearing three pairs of aggenital setae $\left(a g_{1-3}\right)$. Lengths of ventral setae as follows: $1 a 10,3 a 14$, $4 a 10,1 a-1 a 20,3 a-3 a 33,4 a-4 a 33 . a g_{1} 7, a g_{2} 7, a g_{3} 7, p s_{1} 18, p s_{2} 16, p s_{3} 12$.

Legs (Figs 4C-F). Lengths: leg I 122, leg II 94, leg III 105, leg IV 115. Counts of setae on legs I-IV:

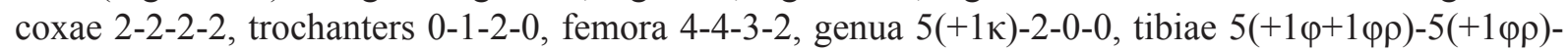

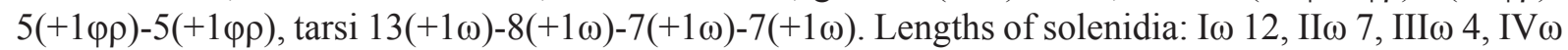
3.

\section{Male and immature stages \\ Unknown.}

\section{Distribution}

Iran (Bagheri \& Zarei 2012; Hajizadeh et al. 2013; Beyzavi et al. 2013; Navaei-Bonab et al. 2015; Rahmati et al. 2015).

\section{Remarks}

Stigmaeus miandoabiensis was described from Iran by Bagheri \& Zarei (2012). Hajizadeh et al. (2013) and Beyzavi et al. (2013) compiled checklists of Iranian prostigmatic mites, which equally included S. miandoabiensis. Later, Navaei-Bonab et al. (2015) and Rahmati et al. (2015) also mentioned this species briefly.

Stigmaeus miandoabiensis is very close to S. planus Kuznetzov, 1978, but it can be distinguished from the latter by $e_{2}$ situated on minute platelets (on striate integument in $S$. planus), $a g_{1}-a g_{4}$ on the same shield ( $a g_{1,2}$ on one shield and $a g_{3,4}$ on another shield in S. planus), and longer ve. 
Table 2. The number of raphignathoid mite species known from Turkey.

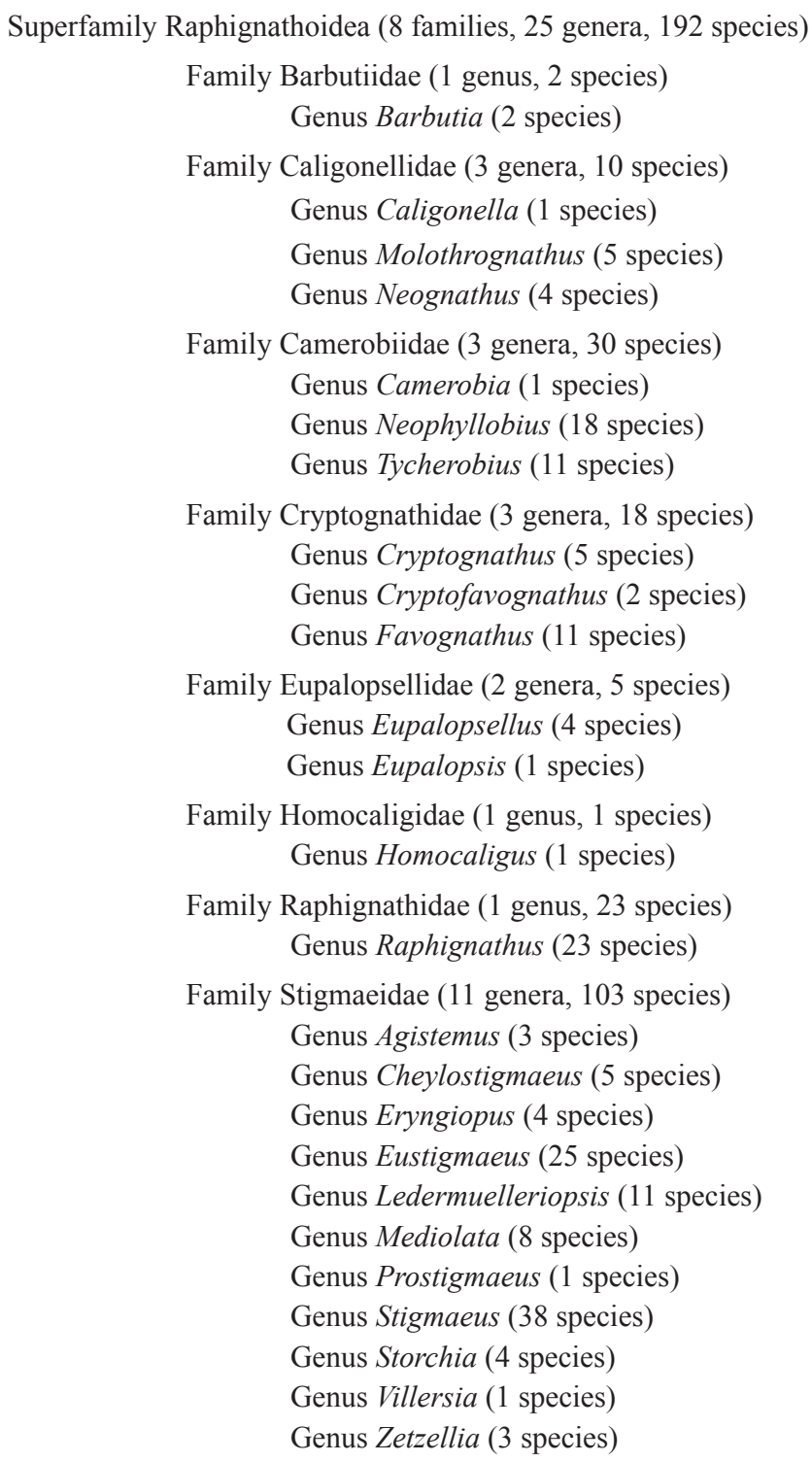

This species is a new record for Turkish fauna, and its deutonymph was identified for the first time in this study. Generally, the Turkish specimens are similar to the type specimens except for the fact that the anterior and posterior regions of the propodosomal shield are covered with tubercles.

\section{Discussion}

The superfamily Raphignathoidea belongs to the suborder Prostigmata. They are worldwide in distribution, abundant in most geographical regions, and are even found in the Antarctic region (Fan \& Zhang 2005). Most raphignathoid mites are known from the drier edaphic microhabitats such as litter, soil, bark and moss (Doğan et al. 2014). Raphignathoidea comprises 11 families, eight of which have been recorded from Turkey: Barbutiidae, Caligonellidae, Camerobiidae, Cryptognathidae, Eupalopsellidae, Homocaligidae, Raphignathidae and Stigmaeidae (Doğan 2007; Erman et al. 2007; Doğan et al. 2014). Until now, 192 raphignathoid mite species (including the two species in this paper) in 25 genera have been found in Turkey (Table 2). 
Stigmaeidae, a family within the superfamily Raphignathoidea, is a large cosmopolitan group of genera distinguished by the position of the dorsal shields, number of subcapitular setae, size of the palptibial claw, shape of the terminal eupathidia on the palptarsus, cheliceral base fused or free, and presence of coxisternal shields (Dönel \& Doğan 2011). Currently, it consists of 33 genera (excluding Erynglpusopsis Tseng, 1982 accepted as synonym of Eryngiopus Summers, 1964 by Doğan et al. [2015b]) and more than 575 species (Fan 2005; Dönel \& Doğan 2011; Zhang et al. 2011; Fan \& Flechtmann 2015; Doğan et al. 2015a, 2015c; Fan \& Ueckermann 2016; Fan et al. 2016). The genus Stigmaeus is one of the oldest and most diverse genera in the Stigmaeidae (Fan \& Zhang 2005) with 133 valid species (Fan \& Zhang 2005; Doğan et al. 2015a, 2016; Dilkaraoğlu et al. 2016a, 2016b, Fan et al. 2016). To date, 36 species of the genus Stigmaeus have been reported from Turkey (Özkan et al. 1988, 1994; Erman et al. 2007; Doğan 2007; Doğan et al. 2015a, 2016; Dilkaraoğlu et al. 2016a, 2016b). In this paper, we described one new species and reported a new record of Stigmaeus from Turkey. This raises the total number of Stigmaeus species for Turkey to 38.

Some variations and asymmetric morphological abnormalities in the species are noted. In both Stigmaeus species, the shape of some dorsal body setae vary. Some setae are slightly serrated, whereas others are smooth (Figs 2A, 5A). Among the paratypes of Stigmaeus bifurcus sp. nov., in one specimen the left seta $c_{1}$ is about two times as long as the right (Fig. 1C). Seta $h_{3}$ is absent on right suranal shield in another paratype of the new species (Fig. 1D).

\section{Acknowledgements}

We would like to thank the Erzincan University, Coordinatorship of Scientific Research Projects, which financially supported this study (research project number FEN-E-140613-0018). This study is a part of the first author's MSc thesis.

\section{References}

Bagheri M. \& Zarei E. 2012. Stigmaeus miandoabiensis sp. nov. (Acari: Trombidiformes: Stigmaeidae), with redescription of S. siculus (Berlese, 1883) from Iran. Systematic and Applied Acarology 17: 441447. https://doi.org/10.11158/saa.17.4.13

Bagheri M., Rahimi G., Maleki N., Gharekhani G. \& Saber M. 2014. Stigmaeus hashtrudiensis, a new species of the genus Stigmaeus (Acari: Trombidiformes: Stigmaeidae) from Northwest Iran. Persian Journal of Acarology 3: 121-128.

Beyzavi G., Ueckermann E.A., Faraji F. \& Ostovan H. 2013. A catalog of Iranian prostigmatic mites of super families Raphignathoidea and Tetranychoidea (Acari). Persian Journal of Acarology 2: 389-474.

Dilkaraoğlu S., Doğan S., Erman O., Sevsay S. \& Adil S. 2016a. Some morphological variations and abnormalities in females of Stigmaeus longipilis (Canestrini) (Acari, Stigmaeidae). Turkish Bulletin of Entomology 6: 149-159. [In Turkish] https://doi.org/10.16969/teb.06297

Dilkaraoğlu S., Doğan S., Erman O., Sevsay S. \& Adil S. 2016b. Stigmaeid mites (Acari: Raphignathoidea: Stigmaeidae) of Harşit Valley and Örümcek Forests (Turkey). Erzincan University Journal of Science and Technology 9: 10-72. https://doi.org/10.18185/eufbed.18373

Doğan S. 2006. Contributions to the knowledge of the raphignathoid mites of Turkey (Acari Raphignathoidea) with description of a new species. International Journal of Acarology 32: 371-375. https://doi.org/10.1080/01647950608684484

Doğan S. 2007. Checklist of raphignathoid mites (Acari: Raphignathoidea) of Turkey. Zootaxa 1454: 1-26. 
BİNGÜL M. et al., Contributions to the knowledge of the mite genus Stigmaeus

Doğan S., Dilkaraoğlu S., Aksoy H., Aykut M. \& Fan Q.-H. 2014. New occurrence of the hygrobiotic mite family Homocaligidae (Acari, Raphignathoidea) in Turkey: Homocaligus crassipus Fan. Systematic \& Applied Acarology 19: 447-461. https://doi.org/10.11158/saa.19.4.8

Doğan S., Bingül M., Dilkaraoğlu S. \& Fan Q.-H. 2015a. Description of a new species of the genus Stigmaeus Koch (Acari: Stigmaeidae) from Turkey, with a list of described species in the world. International Journal of Acarology 41: 290-299. https://doi.org/10.1080/01647954.2015.1028441

Doğan S., Dilkaraoğlu S., Fan Q.-H., Erman O., Sevsay S. \& Adil S. 2015b. Description of a new species of the genus Eryngiopus Summers (Acari: Stigmaeidae) from Turkey. Systematic and Applied Acarology 20: 431-440. https://doi.org/10.11158/saa.20.4.8

Doğan S., Dilkaraoğlu S., Fan Q.-H., Sevsay S., Erman O. \& Adil S. 2015c. Description a species of the genus Cheylostigmaeus Willmann (Acari: Stigmaeidae) from Ekşisu Marsh, Turkey. Systematic and Applied Acarology 20: 797-808. https://doi.org/10.11158/saa.20.7.8

Doğan S., Dilkaraoğlu S., Erman O., Faraji F., Bingül M., Zeytun E. \& Ersin F. 2016. Redescription of Stigmaeus solidus Kuznetzov (Acari, Stigmaeidae) based on the Turkish and Dutch specimens. Turkish Bulletin of Entomology 6: 33-42. [In Turkish] https://doi.org/10.16969/teb.41380

Dönel G. \& Doğan S. 2011. The stigmaeid mites (Acari: Stigmaeidae) of Kelkit Valley (Turkey). Zootaxa 2942: 1-56.

Erman O., Özkan M., Ayyıldız N. \& Doğan S. 2007. Checklist of the mites (Arachnida: Acari) of Turkey. Second supplement. Zootaxa 1532: 1-21.

Fan Q.-H. 2005. Synopsis of the described Actinedida of the world, family Stigmaeidae. In: Hallan J. (ed.) Synopsis of the Described Arachnida of the World. Available from http://bug.tamu.edu/research/ collection/hallan/acari/Family/Stigmaeidae.txt [accessed 17 May 2015]

Fan Q.-H. \& Flechtmann C.H.W. 2015. Stigmaeidae. In: Carrillo D., de Moraes G.J. \& Peña J. (eds) Prospects for Biological Control of Plant Feeding Mites and Other Harmful Organisms: 185-206. Progress in Biological Control 19, Springer International Publishing, Switzerland. https://doi. org/10.1007/978-3-319-15042-0 7

Fan Q.-H. \& Ueckermann E.A. 2016. Resurrection of the genus Nonocaligus Habeeb with redefinition of Nonocaligus and Mullederia Wood (Acari: Stigmaeidae). Systematic and Applied Acarology 21: 1447-1449. https://doi.org/10.11158/saa.21.11.1

Fan Q.-H. \& Zhang Z.-Q. 2005. Fauna of New Zealand. Vol. 52: Raphignathoidea (Acari: Prostigmata). Manaaki Whenua Press, Lincoln.

Fan Q.-H., Flechtmann C.H.W. \& De Moraes D.J. 2016. Annotated catalogue of Stigmaeidae (Acari: Prostigmata), with a pictorial key to genera. Zootaxa 4176: 1-199. https://doi.org/10.11646/ zootaxa.4176.1.1

Grandjean F. 1944. Observations sur les acariens de la famille des Stigmaeidae. Archives des Sciences physiques et naturelles 26: 103-131.

Hajizadeh J., Khanjani M., Faraji F. \& Ueckermann E.A. 2013. Stigmaeid mites of Guilan Province of Iran with description of a new species and a checklist for Iranian stigmaeid mites (Prostigmata: Stigmaeidae). International Journal of Acarology 39: 571-579. https://doi.org/10.1080/01647954.201 $\underline{3.850533}$

Kethley J. 1990. Acarina: Prostigmata (Actinedida). In: Dindal D.L. (ed.) Soil Biology Guide: 667-756. John Wiley \& Sons, New York. 
Khanjani M., Pishehvar S., Mirmoayedi A.-N. \& Khanjani M. 2012. Two new eyeless mite species of the genus Stigmaeus Koch (Acari: Stigmaeidae) from western provinces of Iran and description of the male Stigmaeus pilatus Kuznetzov. International Journal of Acarology 38: 504-513. https://doi.org/10 $\underline{.1080 / 01647954.2012 .703690}$

Kuznetzov N.N. 1978. Revision of the genus Stigmaeus (Acariformes, Stigmaeidae). Zoologischeskii Zhurnal 57: 682-694.

Navaei-Bonab R., Kazazi M., Bagheri M., Zarei E. \& Ueckermann E.A. 2015. Stigmaeid and pseudocheylid mite fauna (Acari: Prostigmata) in three northwestern provinces of Iran with description of male and redescription of female of Mediolata belfieldi Momen. Persian Journal of Acarology 4: 373-398.

Özkan M., Ayyıldız N. \& Soysal Z. 1988. Türkiye Akar Faunası. DOĞA TU Zooloji Dergisi 12: 75-85. [In Turkish]

Özkan M., Ayyıldız N. \& Erman O. 1994. Check list of the Acari of Turkey. First supplement. Euraac News Letter 7: 4-12.

Rahmati M., Kheradmand K., Jafari S. \& Bagheri M. 2015. Fauna of Stigmaeidae and Cryptognathidae (Acari: Trombidiformes) of Lorestan province, with two new records for Iran fauna. Journal of Crop Protection 4: 409-418.

Summers F.M. 1962. The genus Stigmaeus (Acarina: Stigmaeidae). Hilgardia 33 (10): 491-537.

Uluçay İ. 2015. Two new records of the genus Stigmaeus (Acari: Trombidiformes: Stigmaeidae) from Turkey. Persian Journal of Acarology 4: 287-295.

Zhang Z.-Q., Fan Q.-H., Pesic V., Smit H., Bochkov A.V., Khaustov A.A., Baker A., Wohltmann A., Wen T.-H., Amrine J.W., Beron P., Lin J., Gabrys G. \& Husband R. 2011. Order Trombidiformes Reuter, 1909. In: Zhang Z.-Q. (ed.) Animal biodiversity: an outline of higher-level classification and survey of taxonomic richness. Zootaxa 3148: 129-138.

Manuscript received: 13 June 2016

Manuscript accepted: 23 August 2016

Published on: 3 April 2017

Topic editor: Gavin Broad

Desk editor: Chloe Chester

Printed versions of all papers are also deposited in the libraries of the institutes that are members of the EJT consortium: Muséum national d'Histoire naturelle, Paris, France; Botanic Garden Meise, Belgium; Royal Museum for Central Africa, Tervuren, Belgium; Natural History Museum, London, United Kingdom; Royal Belgian Institute of Natural Sciences, Brussels, Belgium; Natural History Museum of Denmark, Copenhagen, Denmark; Naturalis Biodiversity Center, Leiden, the Netherlands. 